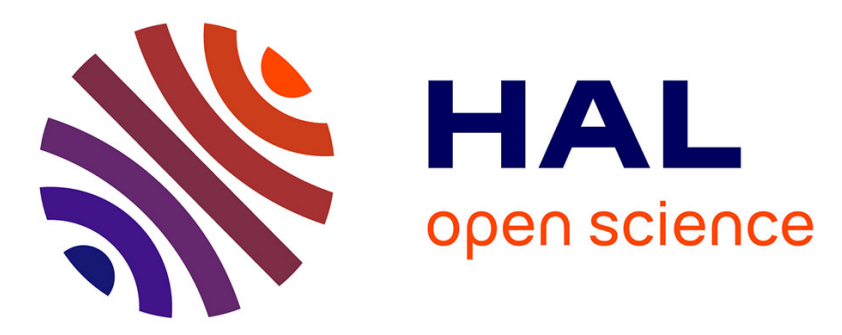

\title{
Investigation of Dynamic Crack Propagation and Arrest for Pulse Loaded specimens Made from a Modified MoV-Steel (KS22) by Means of a Hopkinson-Pressure-Bar
}

\author{
K. Kussmaul, U. Mayer
}

\section{To cite this version:}

K. Kussmaul, U. Mayer. Investigation of Dynamic Crack Propagation and Arrest for Pulse Loaded specimens Made from a Modified MoV-Steel (KS22) by Means of a Hopkinson-Pressure-Bar. Journal de Physique IV Proceedings, 1997, 07 (C3), pp.C3-993-C3-998. 10.1051/jp4:19973167 . jpa-00255457

\section{HAL Id: jpa-00255457 https://hal.science/jpa-00255457}

Submitted on 1 Jan 1997

HAL is a multi-disciplinary open access archive for the deposit and dissemination of scientific research documents, whether they are published or not. The documents may come from teaching and research institutions in France or abroad, or from public or private research centers.
L'archive ouverte pluridisciplinaire HAL, est destinée au dépôt et à la diffusion de documents scientifiques de niveau recherche, publiés ou non, émanant des établissements d'enseignement et de recherche français ou étrangers, des laboratoires publics ou privés. 


\title{
Investigation of Dynamic Crack Propagation and Arrest for Pulse Loaded specimens Made from a Modified MoV-Steel (KS22) by Means of a Hopkinson-Pressure-Bar
}

\author{
K. Kussmaul and U. Mayer
}

\author{
Staatliche Materialprüfungsanstalt (MPA) University of Stuttgart, Pfaffenwaldring 32, 70569 Stuttgart, \\ Germany
}

\begin{abstract}
Experimental and numerical investigations on crack initiation under transient loading, crack propagation behaviour and crack arrest of $17 \mathrm{MoV} 84$ (mod.) using fracture mechanics methods are described. Results of SplitHopkinson-bar-tests using a single-specimen method and a high-speed camera are compared with multi specimen results and values obtained from other specimens and load velocities.
\end{abstract}

\begin{abstract}
Résumé. Ce rapport décrit des études expérimentales et numériques concernant l'initiation des fissures sous charge transitoire, ainsi que leur propagation et arrêt dans le matériau $17 \mathrm{MoV} 84$ (mod.) en utilisant des méthodes de mécanique de fracture. Les résultats des essais Hopkinson avec une méthode à une éprouvette et une caméra à action rapide ont été comparés à ceux obtenus avec plusieurs éprouvettes et aux valeurs d'autres éprouvettes et d'autres vitesses de charge.
\end{abstract}

\section{Introduction}

The deformation and fracture behaviour of steels under high loading rates is quite different from that under quasistatic loading.

It is known that there is an increase in the yield stress as well as a decrease in fracture toughness of ferritic and ferritic-perlitic steels under increasing loading rate [1,2]. These effects occur particularly under plastic strain rate $\dot{\varepsilon}_{\mathrm{pl}}>10^{3} \mathrm{~s}^{-1}$ as they may be found in the plastic zone and the process zone of dynamically loaded cracks. An averaged change rate $\dot{K}$ of the stress intensity factor or the averaged change rate $\dot{J}_{\mathrm{pl}}$ of the plastic part of the J-Integral are used as typical velocity parameter.

A large number of methods is available in the load rate range $\dot{K}>10^{6} \mathrm{MPa} / \mathrm{m}$. A crack is loaded by transient elastic stress fields generated by mechanical shock or explosive load or electro-magnetic forces. Basically one can distinguish between two methods: direct loading of comparably small specimens by a shock [3] and use of a cracked specimen as an elastic wave guide [4]. The advantage of the first atrangement is that the stress pulse loading the crack can precisely be measured. This simplifies the necessary numerical calculation of the near crack field parameter. On the other hand, for the direct shock load it is generally uncertain to determine the boundary conditions necessary for the numerical analysis. To obtain a homogeneous and stable pressure pulse over the cross-section it has to propagate over a long distance. The specimen length can be kept short if a separate reusable waveguide, which is acoustically coupled to a specimen, is used for pulse generation.

The $\mathrm{K}_{\mathrm{Id}}$-determination in this method has been based on an elastodynamic numerical analysis of the test arrangement using the measured loading pulse. Using

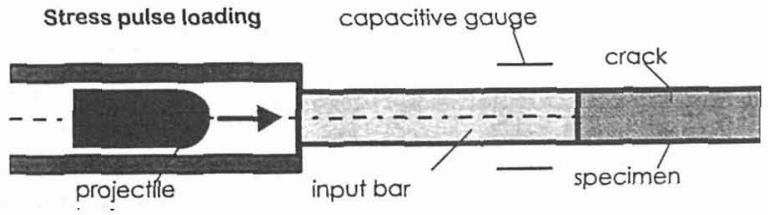

Figure 1: Hopkinson bar fracture test

several identical specimens a critical fracture stress $\sigma_{\text {cris }}$ is determined by variation of the pulse amplitude with simultaneous measuring of the crack propagation, from which $K_{l d}$ follows

$$
K_{l u}=\max \left\{K_{l}(t)\right\}=\sigma_{0} \sqrt{\pi \cdot a} \cdot g(a / w, W \text {, pulse })
$$

$\mathrm{g}(\mathrm{a} / \mathrm{W}, \mathrm{W}$, pulse $)$ is a numerically derived function of the normalized crack length $a / W$, the specimen 
curve.

The advantage of this method is the simple dynamic crack loading, which facilitates the theoretical modelling. Oscillations due to impact loading did not occur because a definite pulse is applied without reflection to the specimen. By measurement of stress in the specimen and in the input bar using strain gauges or a coaxial capacitive gauge this can be very well examined. This method has been used successfully for determining $\mathrm{K}_{\mathrm{Id}}$ on various steels in the lower shelf and the transition area.

\section{Material}

The material KS22 of the research project Integrity of Components (FKS) [5] is a melt based on $17 \mathrm{MoV} 84$. Heat treatment tests were carried out on this material with the aim of obtaining a model material showing low notch impact energy in the upper shelf for isotropic material properties, high brittle fracture transition temperature and high strength. The melt was austenitized at $1050{ }^{\circ} \mathrm{C}$ and tempered at $640{ }^{\circ} \mathrm{C} 7 \mathrm{~h}$. The upper shelf with a notch impact energy of $40 \mathrm{~J}$ to $50 \mathrm{~J}$ is obtained at approx. $300{ }^{\circ} \mathrm{C}$. The NDT temperature was estimated according to P4-criterion at $250^{\circ} \mathrm{C}$, since it was not possible to conduct drop weight tests in this temperature range. Particular characteristics of the bainitic structure of this material are high hardness, large grains (grain size 4 according to ASTM E 112) and many non-metallic inclusions. The specimens were taken out in T-resp. TL direction as in the project "Crack initiation under impact load" [6].

\section{Aim}

Previous investigations have proved [7] that the material $17 \mathrm{MoV} 84$ (mod) is at room temperature in the lower shelf of the notch impact energy temperature curve and fails macroscopically without plastic deformation independent of the loading rate. Therefore, this material is well suited to tests for comparison of the multi-specimen method and a single specimen method (direct measuring of crack start). All investigations were carried out on smooth specimens, i.e. without side grooves and at room temperature. $\mathrm{K}_{\mathrm{Imax}}$ was calculated from the pulse amplitudes and the initial crack length using the dynamic correction functions, discussed above. This yields a fracture toughness $17.6 \mathrm{MPa} \sqrt{\mathrm{m}}<\mathrm{K}_{\text {Id }}<20.5 \mathrm{MPa} \sqrt{\mathrm{m}}$ (at $\dot{\mathrm{K}} \approx$ $2 \cdot 10^{6} \mathrm{MPa} \sqrt{\mathrm{m}} / \mathrm{s}$ ); mean value $\mathrm{K}_{\mathrm{Id}}=19 \mathrm{MPa} \sqrt{\mathrm{m}}$. Results of direct measuring of the crack start using the striation method and the induction probe are $\mathrm{K}_{\mathrm{ld}}=18,5 \mathrm{MPa} \sqrt{\mathrm{m}}$ resp. $\mathrm{K}_{\mathrm{Id}}=23,9 \mathrm{MPa} \sqrt{\mathrm{m}}$ [8]. The results of the crack initiation investigations on tensile stress pulse loaded SECT specimens made of $17 \mathrm{MoV} 84$ (mod.) appeared to be promising for investigations on crack propagation and crack arrest using a high speed camera.

\section{Technique of measuring}

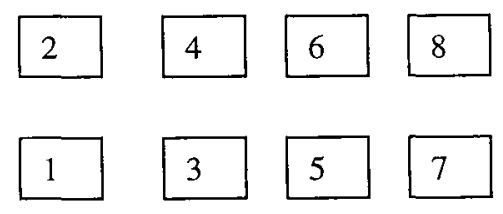

An electronic high-speed image converter camera IMACON 790 by Hadland Photonics was used. The electronic image converter camera converts the picture taken from the photo cathode into an electron beam which is focussed by an electrode. A frame sequence of images on a screen with phosphorescent layers is generated. A sheet film-negative is exposed by the contact method resulting in a frame sequence as presented in Figure 2 .

Figure 2: Arrangement of frame sequence This system enables light amplifying by electronic means. The frame frequency of the camera is determined by plug-ins with up to $2 \cdot 10^{7}$ frames per second (fps). Apart from discrete times of frames so-called streak-pictures are possible using the image converter camera. They consist of a one-dimensional image with continuous resolution in the nanosecond range. The measuring of dislocations and crack extensions is possible. Plug-ins with $1 \cdot 10^{5} \mathrm{fps}, 1 \cdot 10^{6} \mathrm{fps}$ and $2 \cdot 10^{6}$ fps and a plug-in for streak pictures with a continuous resolution of 0.1 up to $1 \mu \mathrm{s} / \mathrm{mm}$ were used. Lenses for $35 \mathrm{~mm}$ cameras can be used for the Image Converter Camera. A micro lens of a 105-mm focal length was used. 


\section{Experiments}

Earlier investigations [9] carried out on ferritic steel in the lower shelf have shown that it was necessary to have a frame rate of $1 \mu \mathrm{s}$ and $0.5 \mu \mathrm{s}$. First aim was to measure the crack propagation of specimens, which were fatigue pre-cracked, to a ratio of approx. a/W=0.31 (crack length $5.5 \mathrm{~mm}$ ) during the first microseconds afer initiation.

Using a micro-lens a 1:1 image resp. a 3-fold enlargement was focused on the luminous screen to record all frames photographically. The high contrast flash illumination of the crack border is of importance to reliable measuring. The change of surface direction in the vicinity of the crack depicts the crack. Though no clear crack could be ascertained on the surface a continuous crack extension can be seen on the photo. Microscopic measurement after tests was used to check the crack extension determined by means of high speed photography.
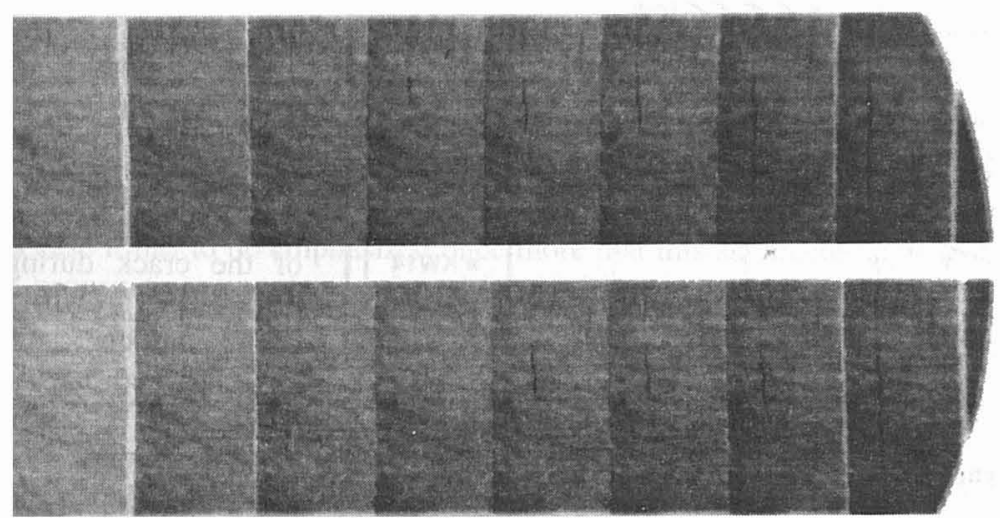

Figure 3: Frame sequence for test KW3 ( $100000 \mathrm{fps}$ )
The first result was that no crack extension occurred during the initial tensile pulse loading of the crack at barely overcritical load. To determine the overall behaviour, a sequence with a frame rate of up to 100.000 per second was taken during several reflections of the stress pulse in the specimen. Three consecutive pulse

loadings could be observed.

Figure 3 shows pictures taken during loading of specimen KW3. The first load takes place between frame 2 and frame 3 . However, no crack propagation could be found. Just after the 8 th resp. 13th frame corresponding to the second or third load by tensile stress pulse a macroscopic crack propagation was detected. Following the third load no additional crack propagation occurred.

An exact numerical treatment is only possible if the crack arrest occurs following a first load of an undamaged material. Therefore the level of the load pulse was increased to such an extent that a macroscopic crack propagation of several millimetres took place.

\begin{tabular}{|c|c|c|c|c|c|c|c|c|c|}
\hline specimen & $\begin{array}{l}\text { fatigue } \\
\text { crack }\end{array}$ & $a_{\text {tot }}$ & $\begin{array}{l}\text { total crack } \\
\text { extension }\end{array}$ & $\begin{array}{l}\text { crack extension } \\
\text { after picture \# }\end{array}$ & $\begin{array}{l}\text { first } \\
\text { picture }\end{array}$ & plug-in & $t_{i}$ & $t_{a}$ & $K_{\max }$ \\
\hline & $\mathrm{a} / \mathrm{mm}$ & $\mathrm{mm}$ & $\mathrm{mm}$ & $\mathrm{mm}(\#)$ & t/ps & & $\mu s$ & $\mu s$ & MPa $/ \mathrm{m}$ \\
\hline KW3 & 5.6 & 8.6 & 3.0 & $1.4(8) / 3.0(13)$ & 85.7 & 1.E5 fps & 105.7 & 105.7 & 24.7 \\
\hline KW7 & 5.5 & 11.5 & 6.0 & $1.9(5)$ & 101.5 & 1.E6 fps & 105.5 & 106.5 & 30.5 \\
\hline KW8 & 5.6 & 13.1 & 7.5 & $2.69(10)$ & 105.4 & 2. E6 fps & 106.9 & 109.9 & 34.1 \\
\hline KW9 & 5.5 & 12.7 & 7.2 & $3.85(17)$ & 102.3 & 2.E6 fps & 104.8 & 110.3 & 34.5 \\
\hline KW11 & 5.5 & 15.4 & 9.9 & $6.2(9)$ & 101.5 & 1.E6 fps & 103.5 & 109.5 & 37.3 \\
\hline KW12 & 5.6 & 14.6 & 9.0 & $4.49(18)$ & 102.3 & 2.E6 fps & 104.3 & 110.8 & 35.4 \\
\hline KW13 & 5.4 & 12.9 & 7.5 & $3.72(16)$ & 102.4 & 2.E6 fps & 103.9 & 109.9 & 34.4 \\
\hline KW14 & 5.4 & 12.8 & 7.5 & $4.0(10)$ & 102.5 & 1.E6 fps & 104.0 & 111.5 & 34.6 \\
\hline KW15 & 5.5 & 16.0 & 10.5 & $7.3(14)$ & 101.6 & 1.E6 fps & 102.6 & 114.6 & 44.1 \\
\hline KW16 & 5.7 & 15.9 & 10.2 & $2.96(41,5)$ & 91.2 & streak & 100.8 & 111.8 & 43.1 \\
\hline
\end{tabular}

Figure 4: Results for crack arrest studies on 17 MoV 84 
The results of these tests are summarised in Figure 4 . The initial crack length a, the crack length $a_{t o t}$ measured after the test, the crack propagation following the test and the maximum crack propagation determined by the high speed measuring are noted. Apart from the plug-in frame rate the initiation time $t_{i}$

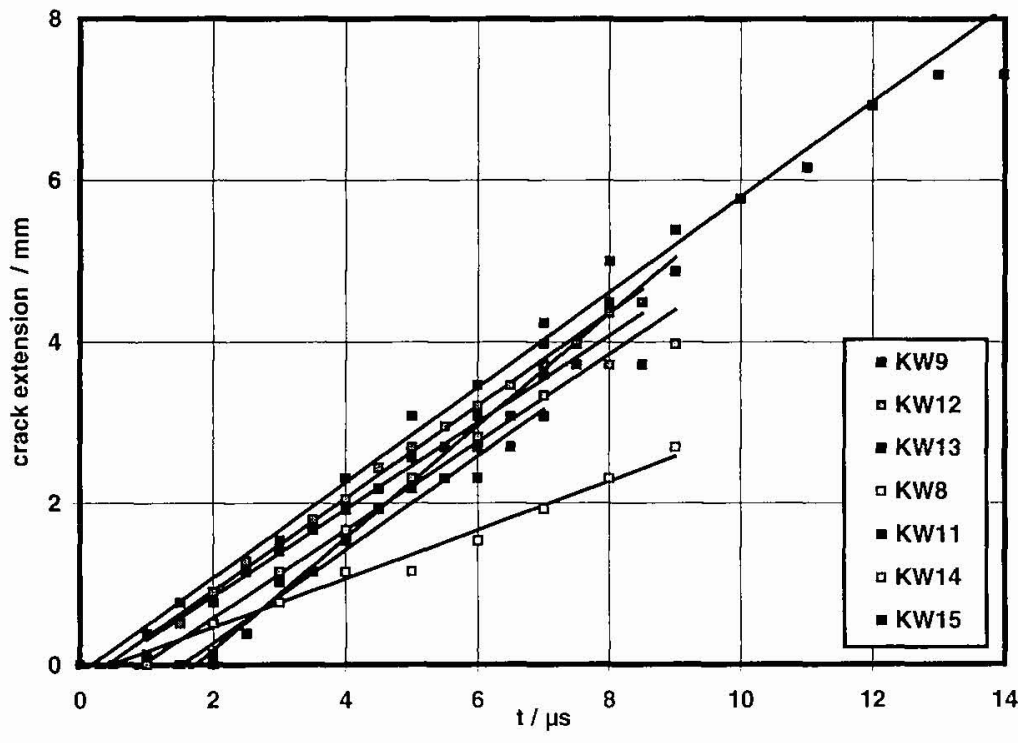

Figure 5: Crack growth for dynamic loading

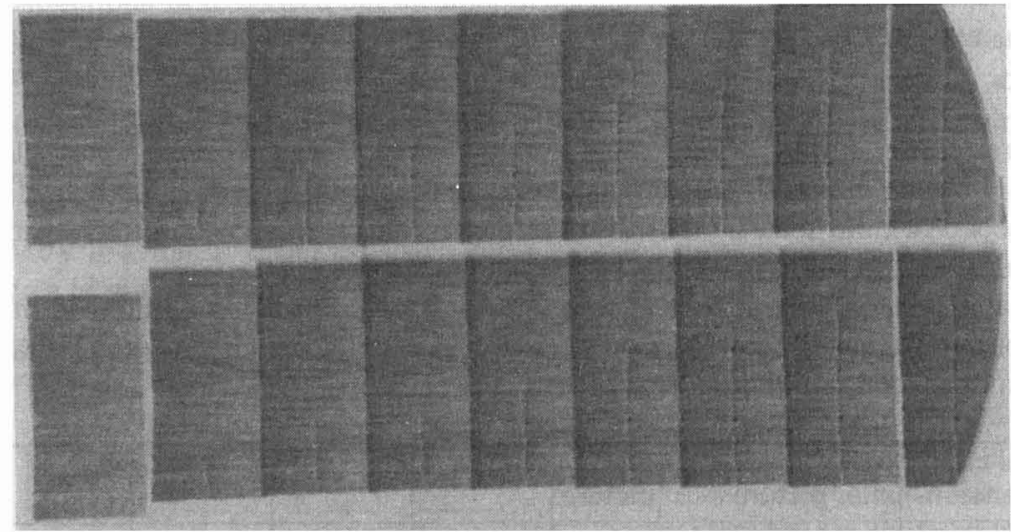

Figure 6: Frame sequence for test KW12 ( $2000000 \mathrm{fps}$ ) and the arrest time $t_{i 1}$ are given. The maximum stress intensity factor $\mathrm{K}_{\max }$ has been calculated from the maximum of the pressure tensile stress pulse, measured on the bar using the function of $\mathrm{a} / \mathrm{W}$ in equation 1 .

Figure 5 shows the time history of the unstable crack growth determined from the high-speed images. An almost constant velocity of the crack during the total crack growth phase can be noticed as found by other authors as well [10].

Figure 6 shows the high-speed frames of test KWI2. The crack propagation is evident from frame to frame. In case of a frame rate of 2 million pictures per second the duration of the crack propagation corresponds exactly to the period covered by 18 frames. Additionally, tests with 1 million frames per second were measured for verification. The total crack propagation during the period of a framing sequence corresponds only to the crack propagation evolving during the first load. The objective of the experimental crack propagation measurement and the corresponding numerical analyses is the maximum load produced by the first tensile stress pulse. The energy stored in the specimen causes further crack propagation in the subsequent loadings. This is not to be discussed here.

Both a dynamic initiation value $\mathrm{K}_{\mathrm{Id}}$ as well as a dynamically determined crack arrest value $\mathrm{K}_{\mathrm{IA}}$ can be determined for the stress intensity factor. The calculation of a time history allows a single specimen test. Previously mentioned investigations found $\mathrm{K}_{\mathrm{ld}}=19 \mathrm{MPa} / \mathrm{m}$ for $17 \mathrm{MoV} 84$ (mod). This value was determined with the multi specimen method. The load was varied in the range, where crack propagation has just been determined. It has not been verified that the measured crack propagation developed during the first load. This distinction of results for single specimen and multi specimen methods was not necessary in earlier investigations [9] on other brittle materials, since they manifested crack propagation already in the first run of an overcritical loading pulse. The crack antest behaviour of the 
$17 \mathrm{MoV} 84(\mathrm{mod})$ does not correspond with the normal one of ferritic steels in the lower shelf. Finally this fact allows the determination of dynamic crack arrest values $\mathrm{K}_{\mathrm{IA}}$ for the stress intensity factor.

The streak image directs a picture of the crack at $2 \mathrm{~mm} / \mu$ s over the screen. Following the picture from left to right one can see the shifting crack tip on a straight line to the top. The constant crack propagation velocity is visible and confirms the results of the single images.

\begin{tabular}{|l|r|r|r|}
\hline Probe & \multicolumn{1}{|c|}{$\mathrm{K}_{\mathrm{Id}}$} & \multicolumn{1}{c|}{$\mathrm{K}_{\mathrm{IA}}$} & \multicolumn{1}{c|}{$\mathrm{K}_{\max }$} \\
\hline KW8 & 32.10 & 29.50 & 36.60 \\
\hline KW9 & 32.80 & 31.00 & 35.40 \\
\hline KW11 & 30.20 & 37.80 & 42.00 \\
\hline KW12 & 31.90 & 32.80 & 34.60 \\
\hline KW13 & 30.90 & 31.20 & 32.70 \\
\hline KW14 & 31.60 & 28.90 & 33.10 \\
\hline KW15 & 33.20 & 33.50 & 42.70 \\
\hline
\end{tabular}

The time history of the stress intensity factor is calculated from the temporal stress pattern taking into consideration the influence of the propagating crack [11]. These calculations were made at the Institut für Technische Physik of the Universität Magdeburg. The moments for crack initiation and crack arrest determined from these images are used to determine $\mathrm{K}_{\mathrm{Id}}$ and $\mathrm{K}$. The results are presented in Figure 7.

Figure 7: Results for crack initiation $K_{I d}$ and crack arrest $K_{I A}$ derived from numerical analysis

The initiation values are higher in this single specimen method than the critical values $K_{\mathrm{ld}}$ determined by the multi specimen method. Within the accuracy obtained $\mathrm{K}_{\mathrm{IA}}$ and $\mathrm{K}_{\mathrm{Id}}$ are equal. However, in this case it has to be emphasized once more that this statement applies only for the first loading pulse. Crack propagation can also be found in specimen loaded with a stress intensity factor below $\mathrm{K}_{\mathrm{Ij}}$, this

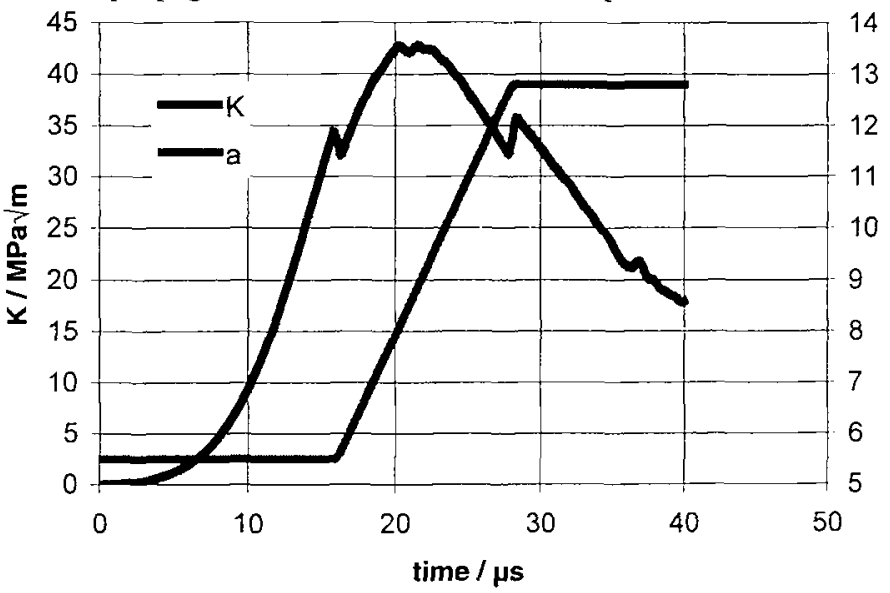

Figure 8: Stress intensity factor $K$ and crack length a vs. time means following loading with decreasing amplitude.

Figure 8 shows the stress intensity factor vs. time for an overcritical test (KW15) taking account of the crack propagation. Additionally the crack propagation behaviour determined from the high-speed images is shown. The transition from the propagating to the arrested crack results in a little oscillation in the numerical calculation. Within this accuracy the stress intensity factor is both at crack start and at crack arrest $32 \mathrm{MPa} \sqrt{\mathrm{m}}$. Specimen which were loaded less showed crack propagation following the test but not after the run of the first stress pulse. Since the load is lower in the following stress pulse than in the first one, local crack propagation resp. damages must have already occurred due to smaller stress without generating a global crack propagation. The shape of the crack propagation front is for the $17 \mathrm{MoV} 84$ (mod.) parallel to the fatigue crack so that the crack propagation measured on the surface of the specimen cannot be distinguished from the average crack propagation as ascertained in other materials [9].

\section{Conclusions}

1. Material $17 \mathrm{MoV} 84$ (mod.) manifests a behaviour deviating from the normal brittle fracture under pulse loading which is understandable because of the local inhomogenity. Therefore, a distinction has to be made between values determined by the multi specimen method and the single specimen method.

2. This material is suitable for investigations on the running crack because there is less difference between specimen surface and specimen centre than for other brittle materials.

3. Crack velocities of approx. $500 \mathrm{~m} / \mathrm{s}$ do not result in a deviation between characteristic values for dynamic crack initiation and crack arrest. 
4. $\mathrm{K}_{\mathrm{IA}}$ of the investigated $17 \mathrm{MoV} 84$ (mod) at room temperature is higher than those $\mathrm{K}_{\mathrm{Ic}}$ values determined on the compact tension specimens in quasistatic tests. This applies to higher temperatures as well. Dynamic calculations [12] made for crack arrest investigations on large-scale specimen lead to $\mathrm{K}_{\mathrm{IA}^{-}}$ values that exceed the $\mathrm{K}_{\mathrm{Ic}}$ scatter band, too.

\section{Acknowledgements}

The investigations were supported by the german government in the project BMFT 1500825 „Rißverhalten bei dynamischer Beanspruchung“.

The authors are grateful to Prof. Dr.R.Clos and Dr. U.Zencker (Institut für technische Physik, Universität Magdeburg ) for the numerical evaluation of the experimental data and their contribution to the understanding of the investigated phenomena.

\section{References}

[1] Hesse, W., K. Brüninghaus, W. Dahl: Yielding and Fracture Behaviour of Ferritic Steels in the Transition Region of Quasistatic to Dynamic Loading, Nucl. Engineering Design 96 (1986), pp. 167.

[2] Stroppe, H., U. Schreppel, R. Clos, R. Schmidt: Experimentelle Methode zur Bestimmung der Bruchzähigkeit von Werkstoffen bei dynamischer Belastung, Wiss. Z. Techn. Hochschule Magdeburg 24 (1984), pp.51.

[3] Kalthoff, J.F.: Fracture Behaviour under High Rates of Loading, Engng.Fract.Mech. 23 (1986). pp.289.

[4] Stroppe, H., U.Schreppel, R.Clos: Dynamic Fracture of Steel at Short Loading Times, in: Impact Loading and Dynamic Behaviour of Materials, Eds.: C.Y.Chiem, H.-D. Kunze, L.W.Meyer, DGMInformationsgesellschaft Verlag, Oberursel, 1988, Vol. 1, pp.161.

[5] Forschungsvorhaben 1500304B Komponentensicherheit (Phase II) - Werkstoffmechanische Untersuchungen, Teil A: Untersuchungen an Kleinproben, Abschlußbericht, MPA Stuttgart, Februar 1990 .

[6] BMFT-Forschungsvorhaben 1500782 "Untersuchungen zur Rißinitiierung unter schlagartiger Belastung", Abschlußbericht, MPA Stuttgart, April 1990.

[7] Demler, T.: Untersuchungen zum Einfluß der Beanspruchungsgeschwindigkeit auf das Festigkeitsund Zähigkeitsverhalten von Feinkornbaustählen, Dissertation Universität Stuttgart, 1990.

[8] BMFT-Forschungsvorhaben 1500 851: Rißverhalten bei Spannungswellenbelastung, Abschlußbericht, Universität Magdeburg, Institut für Technische Physik, 1993.

[9] Clos, R., U.Schreppel, U.Zencker, T.Rahmel, A.Klenk and U.Mayer: Crack Propagation and Arrest Study at Stress Pulse Loading, In: Dynamic Failure of Materials, Eds. H.P.Rossmanith, A.J. Rosakis, Elsevier Appl. Sci., London, New York, 1991, pp.26-41.

[10] Kalthoff, J.F.: Zur Ausbreitung und Arretierung schnell laufender Risse, VDI-Fortschr.-Ber. Reihe $18 \mathrm{Nr} .4,1978$.

[11] Zencker, U. und R. Clos: Numerische elastodynamische Analyse bewegter Risse, Wiss. Z. Techn. Univ. Magdeburg 35 (1991), pp.30-34.

[12] BMFT-Forschungsvorhaben 1500787, Experimentelle und numerische Untersuchungen zum Verhalten eines niedrigzähen Behälterwerkstoffs bei Rißeinleitung, instabiler Rißausbreitung und Rißstopp bei überlagerten mechanischen und thermischen Beanspruchungen, Abschlußbericht Dezember 1992. 